Т.Є. Тарасенко, Л.А. Сивак, Н.О. Верьовкіна, С.А. Лялькін, О.М. Мартинюк, Н.М. Майданевич, H.В. Касап, О.Є. Човган

\title{
Прогнозування перебігу метастатичного люмінального (Her2/neu-негативного) раку грудної залози
}

\author{
Національний інститут раку, Київ \\ Одержано: 22.06 .2020 \\ Підписано до друку: 14.07.2020 \\ DOI: $10.32471 /$ clinicaloncology.2663-466X.37-1.27159
}

\begin{abstract}
Класифікація раку грудної залози (РГЗ) базується не тільки на визначенні розміру первинної пухлини, ураженні лімфатичних вузлів, наявності віддалених метастазів, а й обов'язковим є проведення імуногістохімічного дослідження експресії рецепторів естрогену, прогестерону та епідермального фактора росту - Her2/neu, визначення експресії індексу проліферації пухлинних клітин Кі-67. У 75\% пацієнтів РГЗ експресують рецептори естрогену та належать до люмінальних підтипів. Чутливість РГЗ до гормонотерапії залежить від наявності в пухлині рецепторів, здатних сприйняти гормональний сигнал та транслокувати його в ядро. Імуногістохімічний статус пухлини, що рецидивує, може відрізнятися від результатів первинної біопсії. Актуальним дотепер $є$ пошук неінвазивних маркерів прогнозування чутливості до гормонотерапії у хворих на метастатичний люмінальний РГ3, у тому числі вивчення поліморфних варіантів гена ESR1 (А-351G, Т-397С). Мета дослідження. Підвищити ефективність гормонотерапії інгібіторами ароматази у хворих на метастатичний люмінальний Неr2-негативний РГЗ на підставі вивчення поліморфних варіантів гена ESR1 (A-351G, Т-397C). Об'єкт та методи дослідження. Обстежено та проліковано 53 пацієнтки з метастатичним люмінальним Her2/neu-негативним РГЗ. У 1-й лінії хворі отримали гормонотерапію нестероїдними інгібіторами ароматази. Контроль динаміки процесу за допомогою комп'ютерної томографії проводили кожні 12 тиж лікування згідно з критерями відповіді солідних пухлин на лікування (response evaluation criteria in solid tumors - RECIST 1.1). Cформовано 1-шу групу хворих (прогресування до 12 міс на фоні прийому інгібіторів ароматази) та 2-гу групу (прогресування після 12 міс прийому інгібіторів ароматази). У разі прогресування захворювання пацієнткам проводили забір крові для молекулярногенетичного дослідження поліморфних варіантів A-351G (rs9340799) та T-397C (rs2234693) в 1 інтроні гена ESR1. Результати дослідження свідчать про доцільність визначення мутацій гена естрогенового рецептора (ESR1) у хворих на метастатичний люмінальний Her2/neu-негативний РГЗ для прогнозування перебігу захворювання та вибору персоніфікованого лікування. Висновки. Встановлено, що ризик раннього прогресування захворювання відмічали у пацієнток з метастатичним люмінальним Her2/neu-негативним PГ3 з поліморфними генотипами ESR1 A-351G та ESR1 T-397C - BP=2.81 (BI:1,16 <=BP<=6,82 на рівні значимості $p=0,05)$ та $B P=3,33(B I: 1,00<=B P<=11,90$ на рівні значимості $p=0,05)$.
\end{abstract}

Ключові слова: люмінальний рак грудної залози; гормонотерапія; поліморфізм гена естрогенового рецептора ESR1 (A-351G та T-397C); прогнозування ефективності гормонотерапії.

\section{вступ}

Рак грудної залози (РГЗ) залишається найпоширенішим онкологічним захворюванням у жінок всього світу. Міжнародне агентство з вивчення раку (International Agency for Research on Cancer - IARC) наводить дані про щорічне виявлення 1,4 млн нових випадків цієї онкопатології. В Україні, за даними Національного канцер-реєстру, у 2017 р. діагностовано 14514 випадків РГЗ, з них у 10\% пацієнтів відмічали первинно-метастатичний процес.

Сучасна клініко-патологічна класифікація РГЗ базується на визначенні розміру первинної пухлини (категорія Т), ураженні лімфатичних вузлів (категорія N), ступені диференціації злоякісних клітин, наявності пухлинних емболів у судинах, периневральної інвазії. Обов'язковим є проведення імуногістохімічного дослідження експресії рецепторів естрогену (ER), прогестерону (PR) та епідермального фактора росту Her2/neu [1].

Майже в 75\% усіх випадків пухлинні клітини РГЗ мають ER та належать до люмінальних підтипів РГЗ. Відомо, шо експресія ER клітиною пухлини є чи не єдиним тестом чутливості до гормональної терапії хворих на РГЗ, і саме кількісний вміст стероїдних рецепторів має прогностичне значення [2-3].

Дія естрогенів у клітинах реалізується завдяки їх зв'язуванню з одним 32 специфічних рецепторів $-\alpha$ чи $\beta$, які $€$ ліганд-залежними транскрипційними факторами і належать до суперродини ядерних рецепторів. Ці рецептори синтезуються, відповідно, генами - ESR1 та ESR2. ESR1 локалізується на 6-й хромосомі. Поєднана експресія ER- $\alpha$ i ER- $\beta$ на пухлинних клітинах визначається у більшості випадків РГЗ, проте, тільки підвищення експресії ER- $\alpha$ сприяє чутливості до гормональної терапії антиестрогенами та інгібіторами ароматази [4-5]. Вважається, що обидва рецептори на пухлинних клітинах РГЗ перебувають в антагоністичних відносинах: ER- $\alpha$ переважно стимулює клітинну проліферацію, a ER- $\beta$ належить до супресорів клітинного поділу і втрата його експресії корелює з прогресуванням естрогенонезалежного РГЗ [6-7].

Чутливість пухлини до гормонів визначається збереженням у ній рецепторів, здатних сприйняти гормональний сигнал та транслокувати його в ядро. Сигнальний естрогеновий шлях $€$ прикладом складного біологічного процесу, який контролює безліч функцій, таких як проліферація клітин, апоптоз, інвазія та ангіогенез, що може використовуватися злоякісними клітинами для виживання. Класична функція ER - це його ядерна функція, чи по-іншому, - геномна активність. ER модулює експресію сотні генів, частина з яких стимулюється, а інша, навпаки, пригнічується. Після зв'язування з естрогеном ER димеризується з іншим мономерним рецептором, внаслідок чого приєднується комплекс коактиваторів та корепресорів до конкретних ділянок ДНК. ЕR також може зв'язуватися з іншими факторами транскрипції, такими як activator protein-1 (AР-1) i specificity protein-1 (SP-1) на своїх специфічних ділянках ДНК, тим самим функціонуючи як коактиватор. Сигнальний ER-шлях також регулюється мембранними рецепторними тирозинкіназами, включаючи рецептор епідермального фактора 
росту (epidermal growth factor receptor - EGFR), Her2 та peцептор інсуліноподібного фактора росту (insulin-like growth factor 1 receptor - IGF1-R). Ці мембранні кінази активують сигнальні шляхи, що, зрештою, призводять до фосфорилювання ER, а також його коактиваторів та косупресорів зі зміною ïx специфічних функцій. Подібна активація ER $є$ ліганд-незалежною [8].

Таким чином, у той час як рецепторні тирозинкінази можуть активувати транскрипційну функцію ER, вони також здатні зменшити естрогенову залежність шляхом пригнічення експресії ER, що, можливо, сприяє відносній нечутливості до гормонотерапії (ГТ) [9-10 ].

Виражена експресія ER, як правило, частіше спостерігається у жінок постменопаузального віку, супроводжується низьким рівнем проліферативної активності (Ki-67), високою чи помірною диференціацією пухлинної тканини, низькою частотою супутньої ампліфікації гена Her2/neu, наявністю PR, а при метастатичному процесі - більш повільним перебігом 3 ініціальним ураженням м'яких тканин та кісток [11-12].

Iмуногістохімічне (IГX) дослідження наявності ER залишається й дотепер єдиним лабораторним критерієм визначення доцільності ГТ за необхідності її призначення в ад'ювантному режимі пацієнтам з люмінальним підтипом РГЗ. Згідно з рекомендаціями міжнародних настанов (European Society for Medical Oncology - ESMO, National Comprehensive Cancer Network - NCCN), виконується мультигенний тест гістопрепарату первинної пухлини грудної залози (OncotypeDx), результат якого свідчить про вірогідність розвитку рецидиву хвороби. Завдяки цьому аналізу деякі пацієнти можуть уникнути проведення післяопераційної хіміотерапії та її ускладнень. Деякі хворі, незважаючи на високий рівень ER, не відповідають на лікування ГТ.

Відомо, що IГХ-статус рецидивуючої пухлини може відрізнятися від результатів первинного аналізу. За даними проведеного дослідження DESTINY (2012, Канада) з включенням 121 пацієнтки, рецепторна дискордантність була виявлена у $37,6 \%$ біопсійних матеріалів пацієнток з рецидивами РГЗ. При цьому закономірностей між зміною ER, PR чи Her2/neu-статусу в порівнянні первинних та метастатичних пухлин не виявлено. Проте проведення біопсії з ІГХ-дослідженням у пацієнтів з метастазуванням у легені, кістки чи печінку може бути ускладненим у зв'язку з дрібними вогнищами та недостатністю матеріалу чи високим ризиком ускладнень процедури. Тому актуальним $€$ пошук неінвазивних маркерів прогнозування розвитку нечутливості до ГТ у хворих на метастатичний люмінальний РГЗ.

ГТ залишається пріоритетним методом лікування для первинно-метастатичного ER-позитивного РГЗ завдяки низькому профілю розвитку побічних явищ порівняно з хіміотерапією та тривалим контролем над захворюванням. Проте ії ефективність лімітується високим рівнем виявлення резистентності de novo та на фоні лікування. Лише у близько $30 \%$ пацієнтів з первинно-метастатичним РГЗ відмічають регрес пухлини після ініціальної ендокринотерапії, а у $20 \%$ - стабілізацію хвороби.

Наразі розроблено нові комбінації лікування, спрямовані на блокування перехресних сигнальних шляхів, таких як mTOR та інгібування циклінових комплексів, які призводять до посиленої проліферації клітин [13-14]. Проте спроби підвищення ефективності стандартної ГТ першої лінії тривають. Так, методом молекулярно-генетичного аналізу пухлини у пацієнток з резистентністю до інгібіторів ароматази (IA) виявлено набуті мутації у ER [15-22]. Для генів ESR1/2 відомий ряд однонуклеотидних поліморфізмів, зокрема ESR1 A-351G, ESR1 T-397C, які здатні підвищувати транскрипцію цих генів [23-24]. Такий мутований рецептор зберігає можливість взаємодії з тамоксифеном та фулвестрантом, тому зміна типу ендокринної терапії може супроводжуватися клінічним ефектом. Крім того, аналіз мутацій генів ER у циркулюючій
ДНК може виступати в ролі сурогатного тесту і тому вони потребують додаткового вивчення [25-26].

\section{МЕТА ДОСЛІДЖЕННЯ}

Підвищити ефективність гормонотерапії IA у хворих на метастатичний люмінальний Her2-негативний РГЗ на підставі вивчення поліморфних варіантів гена ESR1 (A-351G, T-397C).

\section{ОБ'ЄКТ І МЕТОДИ ДОСЛІДЖЕННЯ}

У 2017-2019 рр. у відділенні хіміотерапії солідних пухлин Національного інституту раку обстежено та проліковано 53 пацієнтки віком 29-76 років з метастатичним люмінальним Her2/neu-негативним РГЗ. Середній вік хворих становив 51,4 року. Більшість (65\%) хворих перебували в періоді постменопаузи (іх середній вік - 60 років), у інших (35\%) пацієнток менструальна функція була збережена до лікування (середній вік - 36,6 років), що потребувало застосування оваріальної абляції/супресії на фоні гормонотерапії.

Згідно зі стандартами, усім було проведено обстеження: мамографію, ультразвукове дослідження, ІГХ-дослідження трепанобіопсійного матеріалу, комп'ютерну томографію (КТ) органів грудної, черевної порожнин, малого таза з внутрішньовенним контрастуванням, остеосцинтиграфію. В усіх пацієнток не відмічали ознак вісцерального кризу, переважали кісткові метастази у 17 (32\%) хворих, ураження лімфатичних вузлів - у 14 (26\%), метастази у легені - у 11 (21\%) та печінку - у $11(21 \%)$ хворих. Імуногістохімічно підтверджений люмінальний підтип А РГЗ у 16 жінок, а люмінальний В - у 37. У дослідження не включали хворих з експресією епідермального фактора росту Her2.

У якості паліативного лікування усім пацієнткам було призначено 1-шу лінію гормонотерапії нестероїдними IA летрозол (2,5 мг) чи анастрозол (1 мг) щоденно. КТ-контроль динаміки процесу проводили кожні 12 тиж лікування згідно 3 критеріями RECIST 1.1. Сформовано 1-шу групу хворих (прогресування до 12 міс на фоні прийому IA) та 2-гу групу (прогресування після 12 міс прийому IA). У разі прогресування захворювання пацієнткам проводили забір аналізу крові для молекулярно-генетичного дослідження поліморфних варіантів A-351G (rs9340799) та Т-397C (rs2234693) в 1 інтроні гена ESR1 (виконували у Д3 «Референс-центр з молекулярної діагностики МОЗ України», директор - кандидат медичних наук 3.I. Россоха). Використовували модифіковані протоколи з олігонуклеотидними праймерами із застосуванням методу полімеразної ланцюгової реакції та наступним аналізом поліморфізму довжини рестрикційних фрагментів. Досліджувану ділянку гена ампліфікували за допомогою специфічних праймерів («Metabion», Німеччина) із застосуванням комерційного набору DreamTaq Green PCR Master Mix («Thermo Scientific», США). Статистичну обробку матеріалу проводили з використанням пакета Medstatistica. Порівняння достовірності відмінностей середніх величин проводили з використанням t-критерію Стьюдента, кореляційний аналіз проводили з розрахунком коефіцієнта кореляції Пірсона (r). Достовірними вважали дані при $\mathrm{p}<0,05$.

\section{ОТРИМАНІ РЕЗУЛЬТАТИ ТА ЇХ ОБГОВОРЕННЯ}

Досліджували зв'язок результатів лікування з віком пацієнток. Виявлено, що у хворих віком до 50 років відмічали достовірно вищу загальну виживаність (3В) $28,16 \pm 5,25$, ніж у тих, у кого діагноз було встановлено у віці понад 50 років $15,47 \pm 1,9$ ( $\mathrm{p}=0,03)$. Вірогідно, це пов'язано з частішими коморбідними станами у пацієнтів похилого віку, що може бути лімітуючим фактором у разі призначення більш агресивних підходів у лікуванні.

Незважаючи на варіабельність вікового фактора, анамнестично можливо припустити, що ризик розвитку більш агресивних люмінальних карцином (у тому числі з раннім прогресуванням на фоні ГТ) підвищується у жінок, які не мали 
вагітностей (21\% в основній групі проти 8,8\% у контрольній; $\mathrm{p}<0,05)$ чи мали більшу кількість штучного переривання вагітності $(57,8 \%$ у основній групі, 53\% у контрольній групі; p $>0,05)$. У більшості хворих (77\%) був обтяжений гінекологічний анамнез (ендометріоз, синдром полікістозних яєчників, гіперплазія ендометрію), проте без достовірної різниці між групами $(\mathrm{p}>0,05)$.

Відомо, що до незалежних факторів ризику розвитку метастазування пухлин відносять розмір пухлин, ураження регіональних лімфатичних вузлів, судин, статус ER та епідермального фактора росту Her2. Проте характер віддаленого метастазування вивчено недостатньо. Припускають, що певна послідовність генів пов'язана з метастазуванням у кістки та легені, а також зв'язок з рецепторним статусом і підвищеним ризиком метастазування у певні органи [12].

H. Kennecke та співавтори визначили зв'язок молекулярних підтипів РГЗ з локалізацією метастазів та ефективністю лікування [27]. Так, для люмінальних типів відмічали низький ризик метастазування у головний мозок $(2,2-4,7 \%)$, a Her2позитивний та люмінальний Her2-позитивний РГЗ характеризувалися високою частотою уражень головного мозку, печінки, кісток та легень; базальноподібні пухлини часто метастазували в головний мозок $(10,9 \%)$, легені $(18,5 \%)$, кістки $(16,6 \%)$, віддалені лімфатичні вузли $(17,2 \%)$, а іноді - в печінку $(9,3 \%)$. Метастазування у кістки при всіх типах РГЗ становило 30\%, тобто ураження кісток було найчастішим проявом прогресування захворювання.

У нашому дослідженні пацієнток було розподілено на групи з вісцеральними метастазами (легені та печінка) та 3 невісцеральними метастазами (кістки, лімфатичні вузли, м'якотканинні вогнища, яєчники). За результатами дослідження виявлено достовірну різницю у виживаності без прогресування лише у хворих з метастазуванням у легені $12,72 \pm 2,48$ проти $26,25 \pm 3,97$ без їх ураження $(\mathrm{p}<0,05)$.

Цікаво, що значущої різниці у виживаності без прогресування в пацієнток з метастазами в печінку ми не виявили ($20,12 \pm 3,6$ порівняно з 26 $\pm 5,5, \mathrm{p}>0,05)$. Загалом пацієнтки лише 3 невісцеральними метастазами мали тенденцію до кращої виживаності без прогресування порівняно з тими, у кого відмічали вісцеральні метастази $(12,38 \pm 3,1$ та 24,9 93,6 відповідно, $\mathrm{p}>0,05)$. За даними IГX, на всіх гістологічних зразках визначено $\mathrm{ER}$, середне значення яких становило $77,3 \pm 4,07 \%$. У більшості пацієнток відмічали люмінальний В (Her2/neu) тип (70\%), 3 позитивним ER та з низькою експресією PR чи з їх відсутністю (17\% випадків). У середньому відсоток експресії PR становив $39,8 \pm 5,79 \%$. Середнє значення Кі-67 склало $34 \pm 2,93 \%$. Експресія ER була достовірно вищою за наявності експресії PR. Залежність експресії ER від PR виражалася наступною математичною моделлю (табл. 1) ER $=62,95+0,36$ PR. Koeфіцієнти рівняння були достовірні ( $<<0,001)$, модель у цілому була адекватною $(\mathrm{F}=1,94 ; \mathrm{p}<0,001)$.

Таблиця 1. Математична модель залежності між ER та PR за даними ІГХ-дослідження

\begin{tabular}{lcccccc}
\hline \multicolumn{1}{|c}{ 3мінна } & $\mathbf{b}$ & $\mathbf{S}_{\mathbf{b}}$ & $\mathbf{a}$ & $\mathbf{S}_{\mathbf{a}}$ & $\mathbf{t}_{\mathbf{a}}$ & $\mathbf{p}_{\mathbf{a}}$ \\
\hline $\begin{array}{l}\text { Вільний } \\
\text { коефіці- } \\
\text { єнт }\end{array}$ & & & 62,945 & 5,475 & 11,496 & $<0,001$ \\
$\mathrm{PR}$ & 0,515 & 0,149 & 0,362 & 0,105 & 3,456 & 0,002 \\
\hline
\end{tabular}

Загалом медіана часу до прогресування на фоні ГТ 1-ї лінії нестероїдними ІА становила 23,3 міс. Прогресування до 12 міс на фоні ГТ було визначено у 17 хворих та оцінено згідно з критеріями RECIST 1.1, а після 12 міс - у 36 хворих. Аналізуючи залежність медіани часу до прогресування за даними регресійного аналізу, вищі показники виживаності без прогресування виявлено у хворих з високими показниками експресії як ER $(\mathrm{p} \leqslant 0,05)$, так і $\mathrm{PR}(\mathrm{p} \leqslant 0,05)$ (рис. 1,2$)$.

За оцінкою результатів КТ, відповідно до критеріїв RECIST 1.1, найкращою первинною відповіддю на лікування IA було досягнення часткової регресії у 24 (45\%) хворих або

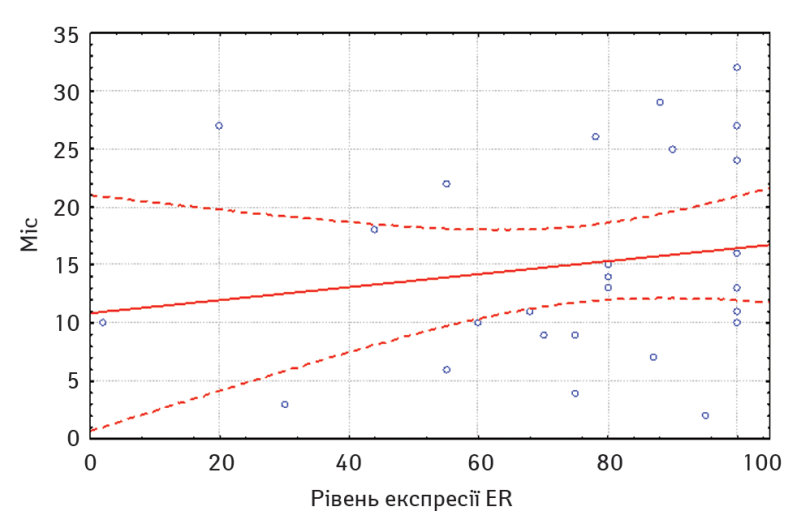

Рис. 1. Залежність медіани часудо прогресування від рівня експресії ER на пухлинних клітинах

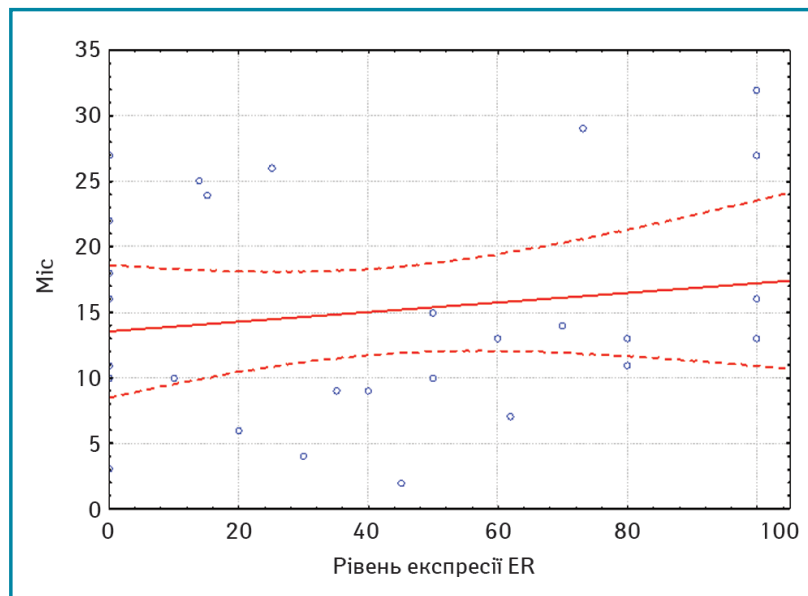

Рис. 2. Залежність медіани часу до прогресування від рівня експресії PR на пухлинних клітинах

стабілізації захворювання - у 16 (30\%). Прогресування захворювання визначено у 13 (25\%) пацієнток.

У групі хворих раннього прогресування захворювання зареєстровано більш високі значення експресії Ki-67, проте дані недостовірні $(\mathrm{p}=0,556)$.

Аналіз розподілу генотипів ESR1 A-351G та ESR1 T-397C у 51,7 та $68,8 \%$ продемонстрував гетерозиготні варіанти у хворих на метастатичний люмінальний Her2/neu-негативний РГЗ 1-ї та 2-ї групи відповідно (табл. 2).

Оцінюючи взаємозв'язок між імуногістохімічними та генетичними даними, достовірної асоціації поліморфізму гена ESR1 (A-351G, T-397C) з IГХ рецепторним статусом (ER i PR) та Ki-67 не виявлено (p>0,5). Проте поліморфний варіант ESR1 A-351G частіше був сполучений з поліморфним варіантом ESR1 T-397C ( $\mathrm{p}=0,0000515$ ) (табл. 3).

Отримані дані дають підстави припустити, що призначення IA призводить до різкого зниження рівня циркулюючих естрогенів та пригнічення ER-опосередкованого сигнального каскаду. У разі селекції пухлинних клітин, що містять мутацію у гені ER, даний рецептор стає активним незалежно від зовнішніх сигналів.

Характер розподілу метастазів у хворих з гетерозиготним варіантом гена ESRI був рівномірним та порівняним між групами (рис. 3).

Встановлено, що наявність поліморфних генотипів ESR1 A-351G та ESR1 T-397C асоціювали з раннім прогресуванням захворювання (до 12 міс) - відповідно відносний ризик $(\mathrm{BP})=2,81$ (вірогідний інтервал (BI): $1,16 \leqslant \mathrm{BP} \leqslant 6,82$ на рівні значимості $\mathrm{p}=0,05)$ та $\mathrm{BP}=3,33$ (BI: $1,00<=\mathrm{BP}<=11,90$ на рівні значимості $\mathrm{p}=0,05$ ) (рис. 4). 
Таблиця 2. Розподіл пацієнтів залежно від показника безрецедивної виживаності до 12 міс та поліморфізмів гена ESR1

\begin{tabular}{lcccc}
\hline \multicolumn{1}{c}{ Безрецидивна виживаність } & $\begin{array}{c}\text { ESR1 A-351G } \\
\text { AA (n) }\end{array}$ & $\begin{array}{c}\text { ESR1 A-351G } \\
\text { AG+GG (n) }\end{array}$ & $\begin{array}{c}\text { ESR1 T-397C } \\
\text { TT (n) }\end{array}$ & $\begin{array}{c}\text { ESR1 T-397C } \\
\text { TC+CC (n) }\end{array}$ \\
\hline До 12 міс (основна група, $n=19)$ & 2 & 7 & 1 & 9 \\
Більше 12 міс (контрольна група, $n=34)$ & 12 & 2 & 17 & 3 \\
\hline
\end{tabular}

Таблиця 3. Розподіл пацієнтів залежно від варіантів поліморфізмів гена ESR1

\begin{tabular}{|c|c|c|c|c|c|}
\hline \multirow{2}{*}{$\begin{array}{c}\text { Генотип } \\
\text { ESR1 A-351G }\end{array}$} & \multicolumn{4}{|c|}{ ESR1 T-397C } & $p$ \\
\hline & $\mathrm{AA}$ & 14 & 3 & 2 & \\
\hline & $A G$ & 4 & 17 & 2 & 0,0000515 \\
\hline & GG & 4 & 2 & 5 & \\
\hline
\end{tabular}

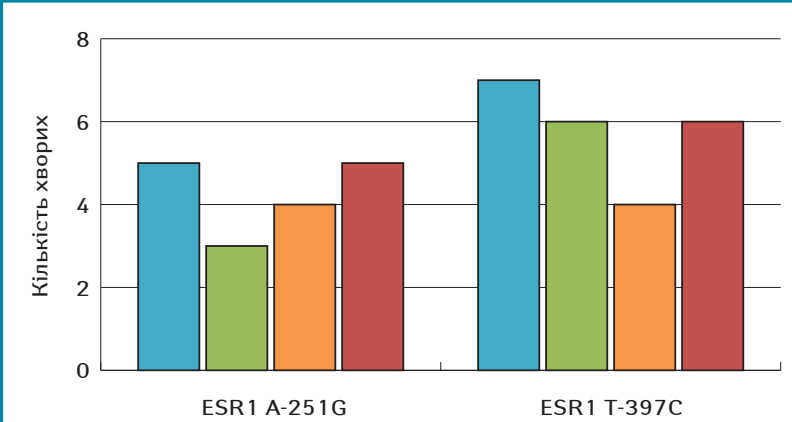

Рис. 3. Розподіл пацієнтів за локалізацією метастазів залежно від поліморфізму гена ESR1

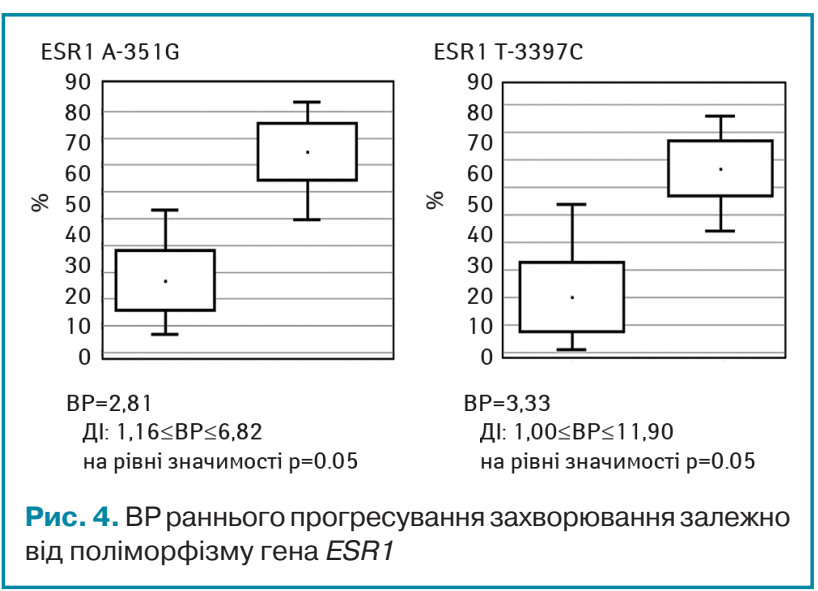

Таким чином, отримані нами результати підтверджують дані щодо доцільності вивчення мутацій гена ESR1 у жінок на етапі планування ГТ, що може слугувати в якості додаткового інформативного маркера прогнозування ефективності ГT IA. Визначення статусу ESR 1 з урахуванням клініко-анамнестичного профілю хворої дозволить умотивовано й більш обгрунтовано підійти до вибору ендокринотерапії та персоніфікувати лікування.

\section{висновки}

1. Несприятливий прогноз захворювання частіше спостерігали у пацієнток віком понад 50 років $(\mathrm{p}=0,03)$ та жінок, які не мали вагітностей чи мали їх штучне переривання $(\mathrm{p}<0,05)$.

2. Досліджено, що найчастішим проявом метастазування у хворих на метастатичний люмінальний Her2/neu-негативний РГЗ було ураження кісток (32\%). Достовірну різницю у виживаності без прогресування визначено лише у хворих з метастазами в легені $(12,72 \pm 2,48$ порівняно з 26,25 $\pm 3,97$ без їх ураження). Кращу виживаність без прогресування відмічали у пацієнтки з невісцеральними метастазами порівняно

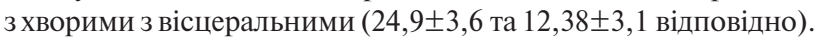

3. Визначено, що поліморфний варіант ESR1 A-351G достовірно частіше асоціювався з поліморфним варіантом ESR1 T-397C ( $\mathrm{p}=0,0000515)$.
4. Встановлено, що ризик раннього прогресування захворювання відмічали у пацієнток з метастатичним люмінальним Her2/neu-негативним РГЗ з поліморфними генотипами ESR1 A-351G та ESR1 T-397C $\mathrm{BP}=2,81$ (BI: $1,16<=\mathrm{BP}<=6,82$ на рівні значимості $\mathrm{p}=0,05$ ) та $\mathrm{BP}=3,33$ (BI: $1,00<=\mathrm{BP}<=11,90$ на рівні значимості $\mathrm{p}=0,05$ ).

\section{СПИСОК ВИКОРИСТАНОÏ ЛІТЕРАТУРИ}

1. Cardoso, F., Kyriakides, S., Ohno, S., Penault-Llorca, F., Poortmans, P., Rubio, I.T., ... Senkus, E. (2019). Early Breast Cancer: ESMO Clinical Practice Guidelines. Annals of Oncology, 30, 1194-1220. doi: 10.1093/annonc/mdz173.

2. Nadji, M., Gomez-Fernandez, C., Ganjei-Azar, P., \& Morales, A. R. (2005). Immunohistochemistry of estrogen and progesterone receptors reconsidered: experience with 5993 breast cancers. American Journal of Clinical Pathology, 123(1), 21-27. doi: $10.1309 / 4 w v 79 n 2 g h j 3 \times 1841$.

3. Bondarenko, I., Mohammad, H., Elhajj, A. V., Prokhach, V. F., \& Zavizion, K. O. Chebanov (2016). Breast cancer. From molecular biology to personified therapy. Morphologia, 10(1),18-25. doi: 10.26641/1997-9665.2016.1.18-25.

4. Gross, J.M., \& Yee, D. (2002). How does the estrogen receptor work? Breast Cancer Research, 4, 62-64. doi: 10.1186/bcr424.

5. Levin, E.R. (2005). Integration of the extranuclear and nuclear actions of estrogen. Molecular Endocrinology, 19, 1951-1959. doi: 10.1210/me.2004-0390.

6. Mosselman, S., Polman, J., \& Dijkema, R. (1996). ER beta: identification and characterization of a novel human estrogen receptor. FEBS letters, 392(1), 49-53. doi: 10.1016/0014-5793(96)00782-x

7. Murphy, L. C., \& Watson, P. H. (2006). Is estrogen receptor-beta a predictor of endocrine therapy responsiveness in human breast cancer? Endocrine-related cancer, 13(2), 327-334. doi: 10.1677/erc.1.01141.

8. AlFakeeh, A., \& Brezden-Masley, C, (2018). Overcoming endocrine resistance in hormone receptor-positive breast cancer. Current Oncology, 25(1): S18-S27. doi: $10.3747 /$ co.25.3752

9. Cardoso, F., Senkus, E., Costa A., Papadopoulos, E., Aapro, M., André, F., ... Winer, E.P. (2018). Advanced Breast Cancer. 4th ESO-ESMO International Consensus Guidelines for. Retrivied from https://www. esmo.org/content/download/181639/3308758/file/Clinical-Practice-GuidelinesSlideset-Advanced-Breast-Cancer.pdf.

10. Osborne, C. K., \& Schiff, R. (2011). Mechanisms of Endocrine Resistance in Breast Cancer. Annual Review of Medicine, 62(1), 233247. doi:10.1146/annurev-med-070909-182917.

11. Roop, R. P., \& Ma, C. X. (2012). Endocrine resistance in breast cancer: molecular pathways and rational development of targeted therapies. Future Oncology, 8(3), 273-292. doi: 10.2217/fon.12.8.

12. Пак, Д.Д., Рассказова, Е. А., \& Данилова, Т. В. (2012). Подтипы рака молочной железы. Опухоли женской репродуктивной системы, 3-4, 13-18.

13. Ignatiadis, M., \& Sotiriou, C. (2013). Luminal breast cancer: from biology to treatment. Nature Reviews Clinical Oncology, 10(9), 494-506. doi: 10.1038/nrclinonc.2013.124.

14. Augereau, P., Patsouris, A., Bourbouloux, E., Gourmelon, C., Lacourtoisie, S. A., Rigaud, D. B., ... Campone, M. (2017). Hormonoresistance in advanced breast cancer: a new revolution in endocrine therapy. Therapeutic Advances in Medical Oncology, 9(5) 335-346. doi: 10.1177/1758834017693195.

15. Heeke, A. L., Pishvaian, M. J., Lynce, F., Xiu, J., Brody, J. R., Chen, W.J., ... Isaacs, C. (2018). Prevalence of Homologous Recombination-Related Gene Mutations Across Multiple Cancer Types. JCO Precision Oncology, 2018, 10. doi:10.1200/PO.17.00286.

16. Toy, W., Shen, Y., Won, H., Green, B., Sakr, R.A., Will, M.

Chandarlapaty, S. (2013). ESR1 ligand-binding domain mutations in hormone-resistant breast cancer. Nature Genetics, 45, 1439-1445. doi: 10.1038/ng.2822.

17. Clatot, F., Augusto, L., \& Di Fiore, F. (2017). ESR1 mutations in breast cancer. Aging (Albany NY), 9(1), 3-4. doi:10.18632/aging.101165.

18. Robinson, D. R., Wu, Y. M., Vats, P., Su, F., Lonigro, R. J., Cao, X., Chinnaiyan, A. M. (2013). Activating ESR1 mutations in hormone-resistant metastatic breast cancer. Nature Genetics, 45, 1446-1451. doi: 10.1038/ng.2823.

19. Jeselsohn, R., Yelensky, R., Buchwalter, G., Frampton, G., Meric-Bernstam, F., Gonzalez-Angulo, A. M.,... Miller, V. A. (2014). Emergence of constitutively active estrogen receptor-a mutations in pretreated advanced estrogen receptor-positive breast cancer. Clinical Cancer Research, 20, 1757-1767. doi: 10.1158/1078-0432.CCR-13-2332.

20. Guttery, D. S., Page,K., Hills, A., Woodley, L., Marchese, S. D., Rghebi, B.,

Shaw, J.A. (2015). Noninvasive detection of activating estrogen receptor 1 (ESR1) mutations in estrogen receptor-positive metastatic breast cancer. Clinical Chemistry, 61(7), 974-982. doi: 10.1373/clinchem.2015.238717.

21. Schiavon, G., Hrebien, S., Garcia-Murillas, I., Cutts, R. J., Pearson, A., Tarazona, N., ... Turner, N. C. (2015). Analysis of ESR1 mutation in circulating tumor DNA demonstrates evolution during therapy for metastatic breast cancer. Science Translational Medicine, 7, 313-182. doi: 10.1126/scitransImed.aac7551.

22. Takeshita, T., Yamamoto, Y., Yamamoto-Ibusuki, M., Inao, T., Sueta, A., Fujiwara, S., ... Iwase, H. (2015). Droplet digital polymerase chain reaction assay for screening of ESR1 mutations in 325 breast cancer specimens. Translational Research, 166, e2. doi: 10.1016/j.trsl.2015.09.003.

23. Палійчук, О.В., Поліщук Л.3., \& Россоха, З.І. (2017). Можливості клінічного використання тестування на поліморфні варіанти генів ESR1 та CYP2D6*4 у хворих на рак грудної залози та ендометрія. Здоровье женщины, 2(118), 132-138. doi: 10.15574/HW.2017.118.132.

24. Lee, Y. H., Kim, J. H. \& Song, G.G. (2014). Genome - wide path way analysis of breast cancer. Tumor Biology, 35(8), 7699-7705. doi: 10.1007/s13277-014-2027-5.

25. Turner. N. C., Jiang. Y., O'Leary. B., Hrebien. S., Cristofanilli. M., Andre. F., .. Loi. S. (2016). Efficacy of palbociclib plus fulvestrant $(P+F)$ in patients (pts) with metastatic breast cancer (MBC) and ESR1 mutations (mus) in circulating tumor DNA (ctDNA) Journal of Clinical Oncology, 34, 512. doi: 10.1200/JCO.2016.34.15 SUPPL.512. 
26. Fribbens, C., O'Leary, B., Kilburn, L., Hrebien, S., Garcia-Murillas, I., Beaney, M., ... Turner, N. C. (2016). Plasma ESR1 Mutations and the Treatment of Estrogen Receptor-Positive Advanced Breast Cancer. Journal of Clinical Oncology, 34 2961-2968. doi: 10.1200/JCO.2016.67.3061.

27. Kennecke, H., Yerushalmi, R., \& Woods, R. (2010). Metostatic behavior of breast cancer subtypes. Journal of Clinical Oncology, 28(20), 3271-3277. doi: $10.1200 /$ JCO.2009.25.9820.

\section{Прогнозирование течения метастатического люминального (Her2/neu-негативного) рака грудной железы \\ Т.Е. Тарасенко, Л.А. Сивак, Н.О. Веревкина, С.А. Лялькин, Е.М. Мартынюк, Н.Н. Майданевич, Н.В. Касап, А.Е. Човган} Национальный институт рака, Киев

Резюме. Классификация рака грудной железы (РГЖ) базируется не только на определении размера первичной опухоли, поражения лимфатических узлов, наличия отдаленных метастазов, но и обязательным является проведение иммуногистохимического исследования экспрессии рецепторов эстрогена, прогестерона и эпидермального фактора роста - Her2/neu, определения экспрессии индекса пролиферации опухолевых клеток Кі-67. У 75\% пациентов РГЖ экспрессируют рецепторы эстрогена и относятся к люминальным подтипам. Чувствительность РГЖ к гормонотерапии зависит от наличия в опухоли рецепторов, способных воспринять гормональный сигнал и транслокировать его в ядро. Иммуногистохимический статус рецидивирующей опухоли может отличаться от результатов первичной биопсии. Актуальным до сих пор является поиск неинвазивных маркеров прогнозирования чувствительности к гормонотерапии у больных метастатическим люминальным РГЖ, в том числе изучение полиморфных вариантов гена ESR1 (А-351G, Т-397С). Цель исследования. Повысить эффективность гормонотерапии ингибиторами ароматазы у больных метастатическим люминальным Her2-отрицательным РГЖ на основании изучения полиморфных вариантов гена ESR1 (А-351G, Т-397С). Объект и методы исследования. Обследовано и пролечено 53 пациентки с метастатическим люминальным Her2/neu-негативным РГЖ. В 1-й линии больные получили гормонотерапию нестероидными ингибиторами ароматазы. Контроль динамики процесса с помощью компьютерной томографии проводили каждые 12 нед лечения в соответствии с критерием ответа солидных опухолей на лечение (response evaluation criteria in solid tumors - RECIST 1.1). Сформирована 1-я группа больных (прогрессирование до 12 мес на фоне приема ингибиторов ароматазы) и 2-я группа (прогрессирование после 12 мес приема ингибиторов ароматазы). В случае прогрессирования заболевания пациенткам проводили забор крови для молекулярно-генетического исследования полиморфных вариантов A-351G (rs9340799) и Т-397C (rs2234693) в 1 интроне гена ESR1. Результаты исследования свидетельствуют о целесообразности определения мутаций гена эстрогеновых рецепторов (ESRI) у больных метастатическим люминальным Her2/neu-негативным РГЖ для прогнозирования течения заболевания и выбора персонифицированного лечения. Выводы. Установлено, что риск раннего прогрессирования заболевания отмечали у пациенток с метастатическим люминальным Her2/neu-негативным РГЖ с полиморфными генотипами ESR1 A-351G и ESR1 T-397C $\mathrm{OP}=2,81$ (ДИ: $1,16<=\mathrm{OP}<=6,82$ на уровне значимости $\mathrm{p}=0,05$ ) и $\mathrm{OP}=3,33$ (ДИ: $1,00<=\mathrm{OP}<=11,90$ на уровне значимости $\mathrm{p}=0,05$ ).

Ключевые слова: люминальный рак грудной железы; гормонотерапия; полиморфизм гена эстрогенового рецептора
ESR1 (А-351G и Т-397C), прогнозирование эффективности гормонотерапии.

Prognostic factors of metastatic luminal (Her2/neunegative) breast cancer

T. Tarasenko, L. Syvak, N. Verevkina, S. Lyalkin, O. Martyniuk, N. Maydanevich, N. Kasap, O. Chovhan

National Cancer Institute, Kyiv

Summary. Types of breast cancer are classified based not only the size of tumor, spread to the lymph nodes or other organs of the body, but it is necessary to assess immunohistochemical (IHC) breast cancer types according to the expression of estrogen receptor (ER), progesterone receptor (PR), Ki-67 proliferative index, and human epidermal growth factor of receptor 2 (Her2). Approximately $75 \%$ of breast cancers are positive for estrogen receptor and, so they are termed the lumainal group. Hormone-sensitive breast cancer is determined by receptors able of perceiving the hormonal signal and translating it into the nucleus. The immunohistochemical status of recurrent tumor can differ from the primary biopsy. The search of noninvasive factors (including of polymorphic ESR1 (A-351G, T-397C) is relevant now for prognoses of hormone therapy in patients with metastatic luminal breast cancer. The aim of the study is to improve the effectiveness of hormone therapy with aromatase inhibitors in patients with metastatic luminal (Her2negative) breast cancer based on the research of the ESR1 gene (A-351G, T-397C) polymorphic variants. The object and methods. Treatment results of 53 patients with metastatic luminal Her $2 /$ neunegative breast cancer, who have been receiving the first-line of endocrine therapy with nonsteroidal aromatase inhibitor. The treatment response assessed every 12 weeks according to RECIST 1.1. In a year of treatment all patients were divided into 2 groups depending on the progression of the disease (I group is the progression up to 12 months and II group is the progression after 12 months). In case of progression disease, we provided molecular genetic testing of ESR1 in peripheral blood. ESR1 (A-351G, T-397C) polymorphism was detected by analysis of DNA restriction fragment length polymorphism in 1 intron of ESR1. The results of the study indicate the feasibility of determining mutations in the estrogen receptor gene (ESRI) in patients with metastatic luminal (Her2/neu-negative) breast cancer to predict the prognoses of the disease and the choice of personalized treatment. Conclusions. It has been established that the presence of polymorphic genotypes ESR1 A-351G (odds ratio (OR) $2.8195 \% \mathrm{CI}=1.16-6.82, \mathrm{p}=0,05$ ) and ESR1 T-397C (OR $3.3395 \% \mathrm{CI}=1,00-11.90, \mathrm{p}=0,05)$ was associated with early disease progression in patients with metastatic luminal (Her2/neu-negative) breast cancer.

Key words: luminal breast cancer; hormone therapy; polymorphisms in the estrogen receptor gene ESR1 (A-351G and T-397C); predicting the effectiveness of hormone therapy.

Aдреса:

Тарасенко Тетяна Свгенівна

О3022 Киів, вул. Ломоносова, 33/43

Національний інститут раку,

E-mail: tarasenko28te@gmail.com 